\title{
A host specialized form of Ceratocystis fimbriata causes seed and seedling blight on native Carapa guianensis (andiroba) in Amazonian rainforests
}

\author{
Denise C.O.F. Valdetaro ${ }^{a}$, Thomas C. Harrington ${ }^{b}$, Leonardo S.S. Oliveira ${ }^{\text {a }}$, \\ Lúcio M.S. Guimarães ${ }^{\mathrm{a}}$, Douglas L. McNew ${ }^{\mathrm{b}}$, Lucas V.A. Pimenta ${ }^{\mathrm{c}}$, \\ Rivadalve C. Gonçalves ${ }^{\mathrm{d}}$, Daniel A. Schurt ${ }^{\mathrm{e}}$, Acelino C. Alfenas ${ }^{\mathrm{a}, *}$ \\ a Programa de Pós-Graduação em Fitopatologia, Universidade Federal de Viçosa, Viçosa, MG 36570-000, Brazil \\ b Department of Plant Pathology and Microbiology, Iowa State University, Ames 50011, IA, USA \\ ${ }^{c}$ Programa de Pós-Graduação em Genética e Melhoramento, Universidade Federal de Viçosa, Viçosa, MG 36570-000, Brazil \\ ${ }^{\mathrm{d}}$ Embrapa Acre - CPAFAC, Rio Branco, Acre 69908-970, Brazil \\ e Embrapa Roraima - CPAFRR, Boa Vista, Roraima 69301-970, Brazil
}

\section{A R T I C L E I N F O}

\section{Article history:}

Received 27 September 2018

Received in revised form

30 November 2018

Accepted 11 December 2018

Available online 14 December 2018

Corresponding Editor: Jullian Rutherford

Keywords:

Host specialization

\begin{abstract}
A B S T R A C T
Ceratocystis fimbriata Ellis \& Halsted recently was recorded causing seed and seedling blight on Carapa guianensis Aubl. (andiroba), a tree species native to the Amazon Rainforest and prized for its valuable timber and medicinal seed oil. C. fimbriata more commonly causes wilt type diseases in woody hosts, especially on non-native host trees. However, on andiroba the disease occurs on seedlings and seeds, affecting the species regeneration. We studied 73 isolates of $C$. fimbriata on andiroba from three regions of the Amazon Basin to see if they represented natural or introduced populations. Analysis of ITS rDNA sequences and phylogenetic analysis of mating type genes revealed new haplotypes of $C$. fimbriata from the Latin American Clade that were closely related to other Brazilian populations of the fungus. In mating experiments, andiroba isolates were inter-fertile with tester strains of $C$. fimbriata from Brazil and elsewhere, confirming that they belong to a single biological species. Using microsatellite markers, 14 genotypes and populations with intermediate levels of genetic variability were found, suggesting that the fungus is indigenous to the Amazon Basin. Inoculation tests indicated that the andiroba isolates are host-specialized on andiroba, supporting the proposition of the special form C. fimbriata f. sp. carapa.
\end{abstract}

๑ 2018 British Mycological Society. Published by Elsevier Ltd. All rights reserved.

\section{Introduction}

Carapa guianensis (andiroba, Meliaceae) is a woody plant native to the Amazon Rainforest (Tropicos, 2016). It is prized for its highly valued wood and seed oil, which is used for cosmetic and medicinal purposes (Herrero-Jáuregui et al., 2013; Klimas et al., 2012; Souza et al., 2006; Vinhote, 2014). Recently, Ceratocystis fimbriata sensu lato (s.l.), was reported on seeds and seedlings underneath naturally established andiroba trees (Halfeld-Vieira et al., 2012). In Brazil, C. fimbriata most commonly causes wilt-type diseases in the woody xylem of non-native timber and fruit-producing trees, such as Mangifera indica L. (mango) (Carvalho, 1938), Gmelina arborea

\footnotetext{
* Corresponding author.

E-mail address: aalfenas@ufv.br (A.C. Alfenas).
}

Roxb. Ex Sm. (gmelina) (Muchovej et al., 1978), Ficus carica L. (fig tree) (Valarini and Tokeshi, 1980), Eucalyptus spp. (Ferreira et al., 1999), Tectona grandis L. f. (teak) (Firmino et al., 2012), and Actinidia deliciosa (A. Chev) CF Lianget \& AR Ferguson (kiwifruit) (Piveta et al., 2013).

Ceratocystis fimbriata is a soilborne pathogen that appears to be native to much of Brazil (Ferreira et al., 2010, 2017; Oliveira et al., 2015a). However, only a few native hosts of C. fimbriata have been identified in Brazil. It has been reported on planted Hevea brasiliensis M. Arg. (rubbertree) (Albuquerque et al., 1972; Valdetaro et al., 2015), but the $C$. fimbriata strains recovered from this host in Acre (Amazon Region) and Bahia (Northeastern Brazil) may not have been native to those areas (Valdetaro et al., 2015). The species causing wilt on Theobroma cacao L. (cacao) was found to be native to the Upper Amazon and was described as a distinct species (Ceratocystis cacaofunesta Engelbr. \& T.C. Harrin.) that is host- 
specialized to that species and is intersterile with all other tested strains in the C. fimbriata complex (Engelbrecht and Harrington, 2005). Recently, C. fimbriata was reported on Caryocar brasiliense, causing wilting and death of trees in the Cerrado vegetation type in the State of Minas Gerais (Silva et al., 2017). Other important populations of $C$. fimbriata in Brazil have been characterized on nonnative hosts, such as mango, eucalyptus, taro, and kiwifruit (Ferreira et al., 2010, 2017; Oliveira et al., 2015a, 2017).

Like $C$. cacaofunesta, the pathogen on andiroba could be a cryptic species native to the Amazon Basin that has specialized to this native host and is no longer sexually compatible with other strains of $C$. fimbriata in Brazil. This work aimed to determine if the population on andiroba is a distinct species by: a) genetically characterizing the pathogen through phylogenetic analyses using ITS rDNA bar-coding and sequences of mating type genes, b) characterizing the population structure of the pathogen using microsatellite markers, c) determining the mating compatibility of andiroba strains with other isolates of $C$. fimbriata from Brazil, and d) evaluating the aggressiveness and host specificity of the pathogen by cross-inoculations on mango, teak, eucalyptus and andiroba.

\section{Materials and methods}

\subsection{Sample collection and fungal isolation}

Andiroba seeds and seedlings with stem blight symptoms and gray to black fungal sporulation on their surfaces were collected in native Amazonian rain forests in the states of Acre (AC, Rio Branco), Amazonas (AM, Boa Vista do Ramos/Parintins) and at two sites in Roraima (RR1 and RR2, São João da Baliza) (Fig. 1). At each site, the samples were collected within a $50 \mathrm{~m}$ radius around an andiroba tree. Seeds and seedlings were brought to the Laboratory of Forest Pathology, DFP/BIOAGRO at the Universidade Federal de Viçosa (UFV). Diseased tissue was placed on carrot baits (Moller and Devay, 1968) and subsequently incubated at room temperature (approximately $25{ }^{\circ} \mathrm{C}$ ) to stimulate perithecium production. A single ascospore mass formed at the top of a perithecium was transferred to a plate with MYEA ( $2 \%$ malt extract, $0.2 \%$ yeast extract, and $2 \%$ agar) (Alfenas and Mafia, 2016; Ferreira et al., 2010). For all isolates, single ascospore strains were obtained from a perithecium formed on MYEA by dispersing an ascopore mass in $10 \mu \mathrm{L}$ of autoclaved mineral oil and streaking the oil over a fresh plate of MYEA. After $24 \mathrm{~h}$, individual germlings were transferred to fresh MYEA plates (Harrington and McNew, 1997). One self-fertile strain per seed or seedling was stored in $15 \%$ glycerol at $-80{ }^{\circ} \mathrm{C}$ at Universidade Federal de Viçosa. Some isolates from andiroba were also stored in the collection at Iowa State University, USA.

\subsection{DNA extraction}

The fungus was grown on MYEA and incubated at $25{ }^{\circ} \mathrm{C}$ for about $7 \mathrm{~d}$ before extracting DNA using the Wizard ${ }^{\circledR}$ Genomic DNA Purification Kit (Promega Inc. - Madison, USA) with the manufacturer's protocol as modified by Valdetaro et al. (2015). The concentration of purified DNA was quantified with a Nanodrop $2000 c^{\circledR}$ (Thermo Fisher Scientific Inc., Massachusetts, USA) and adjusted to $50-100 \mathrm{ng} \mu \mathrm{L}^{-1}$.

\subsection{ITS and mating type genes sequences}

Amplification and sequencing of the ITS rDNA region was performed using the primers ITS1-F (Gardes and Bruns, 1993) and ITS4 (White et al., 1990). The new ITS sequences were compared with those reported earlier for the LAC (Latin American Clade) (Harrington et al., 2011, 2014) using parsimony analyses.

Partial sequences of mating type genes MAT1-1-2 (one of the MAT-1 genes) and MAT1-2-1 (the MAT-2 gene) were amplified and sequenced with primers CFMAT1-F and CFMAT1-R (Harrington et al., 2014) and primers X9978R1R and CFM2-1F, respectively (Harrington et al., 2011). The PCR conditions for amplifying the

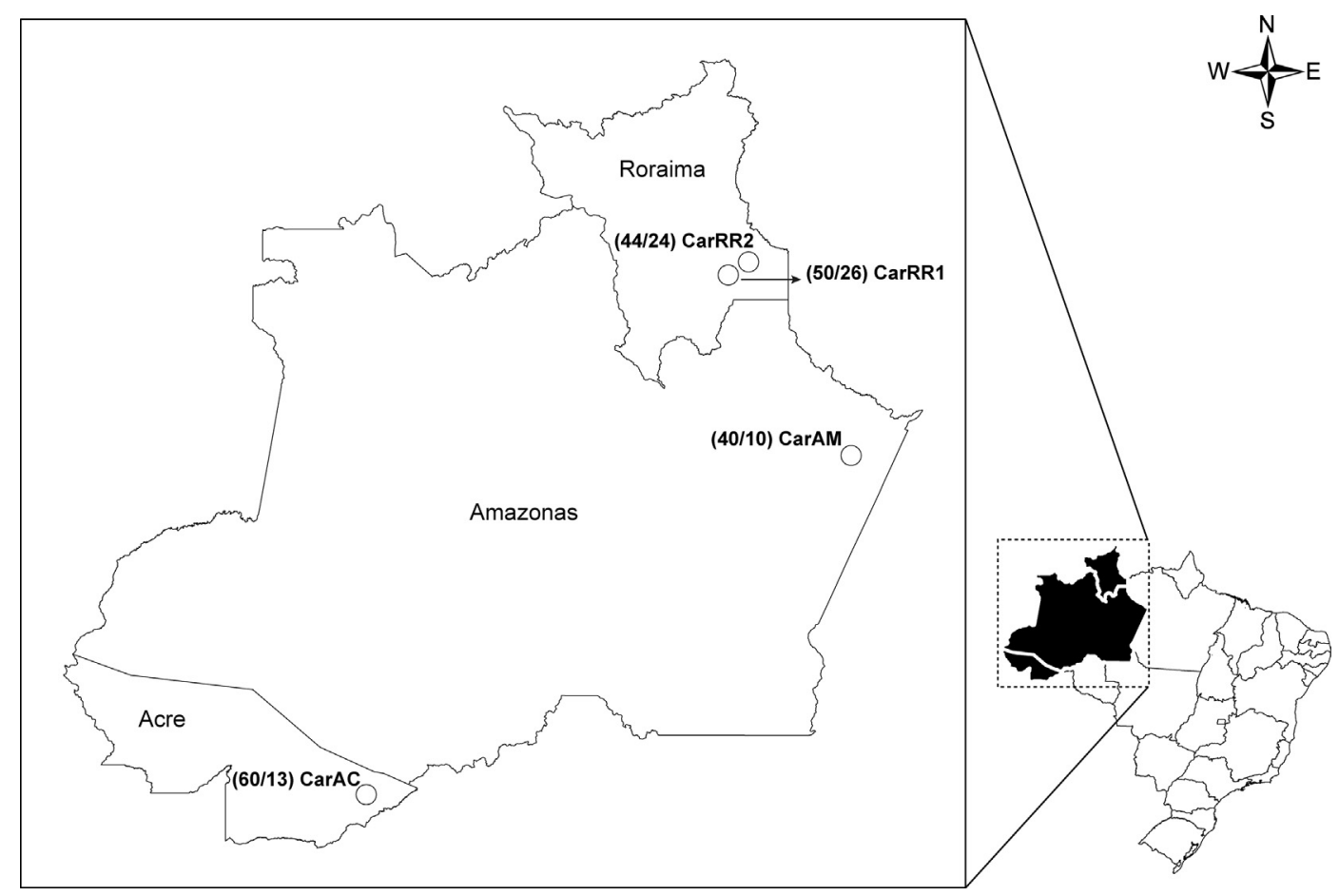

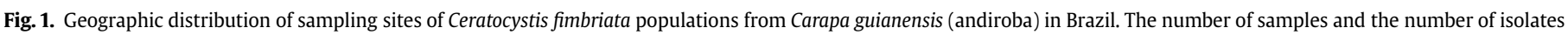
obtained from each population are in parentheses. 
three regions were as described previously (Harrington et al., 2014). The PCR products were purified using Ilustra ${ }^{\mathrm{TM}}$ GFX ${ }^{\mathrm{TM}}$ PCR DNA, and all sequencing was conducted by the Iowa State University DNA Facility. Sequences were analyzed and edited using Sequence Navigator (Applied Biosystems, Foster City, California) software and manually aligned when necessary.

\subsection{Phylogenetic analyses based on mating type genes}

Sequences of the two mating type genes (MAT1-1-2 and MAT12-1) of isolates obtained in this study were compared with representative isolates of the $C$. fimbriata complex, including C. cacaofunesta, C. colombiana M. van Wyk \& M. J. Wingfield and Ceratocystis platani (Walter) Engelbrecht \& T.C. Harrin. (Table 1). Ceratocystis variospora (R.W. Davidson) C. Moreau from the North American Clade (NAC) was used as the outgroup taxon. The partition homogeneity test (PHT) was conducted using PAUP 4.0b1.0 (Swofford, 2003) in order to determine whether the datasets could be combined.

Maximum parsimony (MP) analysis was performed by using PAUP * 4.0b10 (Swofford, 2003) using heuristic searches and the TBR algorithm (Tree Bissection Reconnection), with stepwise addition. Bootstrap values were determined with 1000 random repetitions. Gaps were treated as a fifth base and all characters had equal weight.

Bayesian inference was performed using MrBayes v3.2.1 (Ronquist and Huelsenbeck, 2003). The best model of nucleotide substitution was chosen based on the Akaike information criterion (AIC) of MrModelTest 3.2 (Nylander, 2004). A posterior probability $(P P)$ distribution of trees was created using MCMC (Metropoliscoupled Markov chain Monte Carlo), with four chains (one cold and three heated) initiated from a random tree and one million generations executed, discarding the first 25 percent of the trees by means of the burn-in procedure in MrBayers.

\subsection{Mating experiments}

Self-sterile, single-ascospore strains of isolates from andiroba from each state were selected as MAT-1 (female-only) testers. Selfsterile MAT-2 (male-only) strains were recovered from vegetative sectors that formed spontaneously (Ferreira et al., 2010; Oliveira et al., 2015a). These MAT-2 strains no longer produced perithecia and thus could be used as males only. Other MAT-2 testers included one isolate of $C$. fimbriata from teak, one from Ipomoea batatas (sweet potato), one isolate from Eucalyptus, three isolates from mango, and one isolate of $C$. platani (Oliveira et al., 2015a). To confirm that the MAT-2 testers had the MAT1-2-1 gene, DNA was

Table 1

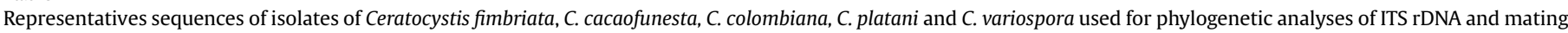
type genes.

\begin{tabular}{|c|c|c|c|c|c|c|}
\hline Species & Hosts & Localization & Representative isolate & $\begin{array}{l}\text { ITS sequence } \\
\text { acessions }\end{array}$ & $\begin{array}{l}\text { MAT1-1-2 GenBank } \\
\text { accessions }\end{array}$ & MAT1-2-1 GenBank accessions \\
\hline \multirow[t]{20}{*}{ C. fimbriata } & Carapa guianensis & Acre, Brazil & CarAC-144C3 & MH687340 & $a_{-}$ & - \\
\hline & Carapa guianensis & Acre, Brazil & CarAC-144B2 & - & MH744812 & MH744820 \\
\hline & Carapa guianensis & Amazonas, Brazil & CarAM-MA2 & MH687341 & MH746809 & MH746810 \\
\hline & Carapa guianensis & Roraima, Brazil & CarRR1-RR74 & - & MH744813 & MH744821 \\
\hline & Tectona grandis & Mato Grosso, Brazil & TecMT-QM22 & MH687342 & MH744814 & MH744822 \\
\hline & Tectona grandis & Mato Grosso, Brazil & TecMT-RC353 & MH687343 & - & - \\
\hline & Hevea brasiliensis & Acre, Brazil & HevAC-RB08 & MH687344 & MH744815 & MH744823 \\
\hline & Hevea brasiliensis & Bahia, Brazil & HevBA-A50 & MH687345 & MH744816 & MH744824 \\
\hline & Actinidia deliciosa & Rio Grande do Sul, Brazil & PP14 & - & MH744817 & MH744825 \\
\hline & Actinidia deliciosa & Rio Grande do Sul, Brazil & PM20 & - & MF347680 & MF347678 \\
\hline & Cajanus cajan & Distrito Federal, Brazil & $\mathrm{C} 2173$ & MH687346 & - & - \\
\hline & Theobroma cacao & Trinidad and Tobago & C1584 & - & MH744818 & МH744826 \\
\hline & Ficus carica & São Paulo, Brazil & C1782 (=CBS 115 166) & AY526292 & KF482987 & HQ157551 \\
\hline & Ficus carica & São Paulo, Brazil & C1857 & HQ157542 & same as KF482987 & same as HQ157551 \\
\hline & Gmelina arborea & Pará, Brazil & C918 (=CBS 115 173) & AY157967 & KF482983 & HQ157549 \\
\hline & Eucalyptus spp. & Bahia, Brazil & $\mathrm{C} 1442(=\mathrm{CBS} 115$ 174) & HQ157545 & KF482985 & HQ157550 \\
\hline & Eucalyptus spp. & Bahia, Brazil & C1440 & HQ157544 & same as KF482985 & same as HQ157550 \\
\hline & Eucalyptus spp. & Bahia, Brazil & C1985 & AY157966 & same as KF482985 & same as HQ157550 \\
\hline & Eucalyptus spp. & Bahia, Brazil & $\mathrm{C} 2123$ & AF395685 & - & - \\
\hline & Eucalyptus spp. & Paraná, Brazil & C1987 & - & KF482990 & HQ157552 \\
\hline \multirow[t]{12}{*}{ C. fimbriata } & Mangifera indica & Pernambuco, Brazil & C1970 & $a_{-}$ & KF482986 & HQ157550 \\
\hline & Mangifera indica & Rio de Janeiro, Brazil & C2055 & HQ157548 & same as KF482986 & same as HQ157550 \\
\hline & Mangifera indica & São Paulo, Brazil & C1657 & AY526291 & same as KF482986 & same as HQ157550 \\
\hline & Mangifera indica & Pernambuco, Brazil & C1968 & AY585343 & KF482984 & HQ157553 \\
\hline & Mangifera indica & Rio de Janeiro, Brazil & C2094 & - & KF482987 & KF482998 \\
\hline & Mangifera indica & Rio de Janeiro, Brazil & C1558 (=CBS 115 175) & AY157965 & KF482988 & HQ157552 \\
\hline & Mangifera indica & São Paulo, Brazil & C1655 & HQ157546 & - & - \\
\hline & Mangifera indica & São Paulo, Brazil & C1889 & HQ157547 & - & - \\
\hline & Mangifera indica & São Paulo, Brazil & C994 (=CBS 600.70) & AY157964 & KF482987 & HQ157551 \\
\hline & Colocasia esculenta & São Paulo, Brazil & C1905 (=CBS 115 171) & AY526288 & KF482989 & HQ157552 \\
\hline & Colocasia esculenta & São Paulo, Brazil & C1926 & HQ157541 & - & - \\
\hline & Ipomoea batatas & Papua New Guinea & C1476 (=ICMP 8579) & AY157957 & KF482992 & KF483000 \\
\hline \multirow[t]{3}{*}{ C.cacaofunesta } & Theobroma cacao & Ecuador & $\mathrm{C} 1004(=\mathrm{CBS} 153.62)$ & AY157950 & KF482993 & KF483001 \\
\hline & Theobroma cacoa & Bahia, Brazil & C1587 & AY157953 & - & - \\
\hline & Theobroma cacoa & Rondônia, Brazil & C2031 & MH687347 & MH744819 & MH744827 \\
\hline \multirow[t]{2}{*}{ C.colombiana } & Coffea arabica & Colombia & C1543 (=CBS 135861$)$ & AY157961 & KF482994 & KF483002 \\
\hline & Coffea arabica & Colombia & C1024 & MH687348 & same as KF482994 & same as KF483002 \\
\hline C. platani & Platanus accidentalis & North Carolina, USA & $\mathrm{C} 1317$ (=CBS 115 162) & AY157958 & KF482995 & KF483003 \\
\hline C. variospora & Prunus sp. & Iowa, USA & C1963 (=CBS 135862$)$ & AY907042 & KF482996 & KF483004 \\
\hline
\end{tabular}

a Not used in analyses. 
extracted and PCR was conducted using the primers CFM2-1 and X9978R1R (Oliveira et al., 2015a).

The male (MAT-2) and female (MAT-1) testers were grown on MYEA for $7 \mathrm{~d}$ at room temperature. A suspension ( $1 \mathrm{~mL}$ ) of conidia (the male tester) was dispersed over the female colony for spermatization (Ferreira et al., 2010; Oliveira et al., 2015a). The cultures were observed during the next 3-4 wk for the presence of perithecia and ascospore masses using a dissecting microscope. Drops of ascospores at the tip of perithecia were characterized as opaque (normal appearance, indicating an intraspecific cross) or watery (indicating a hybrid cross with few or no ascospores). Ascospore masses were spread onto fresh MYEA and colonies were examined after $1 \mathrm{wk}$ to determine if the progeny were viable and a mixture of phenotypes were evident. In successful crosses, the progeny showed the mycelial phenotypes of the two parents. However, in some pairings, the progeny showed a uniform mycelial morphology, indicating an induced selfing had occurred (Ferreira et al., 2010; Oliveira et al., 2015a). The experiment was repeated twice and the two tester strains were considered interfertile if normal acsospore masses (opaque, non-watery) and mixed phenotypes among the progeny were found in at least one of the two crossings.

\subsection{Microsatellite analyses}

Fourteen microsatellite loci developed by Steimel et al. (2004) and later mapped onto the $C$. fimbriata genome (Simpson et al., 2013) were analyzed. These microsatellite markers have been widely used in studies of population structure involving species within the LAC, especially in other Brazilian populations (Engelbrecht et al., 2004, 2007a; Ferreira et al., 2010, 2011; 2017; Harrington et al., 2015; Li et al., 2016; Ocasio-Morales et al., 2007; Oliveira et al., 2015a; Valdetaro et al., 2015). Each primer pair was specific to the flanking region of a simple sequence repeat, and one of the primers was fluorescently labeled. The PCR conditions were as described (Ferreira et al., 2010), and band sizes of the product were determined using a four-capillary ABI Prism 3100- Genetic Analyzer (Applied Biosystems Inc., Foster City, CA) and ABI Peak Scanner v1.0 Analysis Software (Life Technologies). Each product length (within $1 \mathrm{bp}$ ) was considered to be a different allele, but most of the microsatellite loci were trinucleotide repeats, and the products differed by increments of $3 \mathrm{bp}$.

Genetic variation of andiroba populations was compared with representative Brazilian C. fimbriata populations on teak, Colocasia esculenta (taro) (Oliveira et al., 2017), Eucalytpus (Ferreira et al., 2010) and mango (Oliveira et al., 2015a) using the same microsatellite markers. Nei's gene diversity $(H)$ for each population was calculated without and with clone-corrected data using PopGene 1.32 software. Multilocus genotypic diversity was estimated using rarefaction curves based on the smallest sample size (Grünwald et al., 2003) with the Vegan package from CRAN in R v.2.6.1 ( $R$ Core Team, 2007). The maximum value of $G$ was 5 for comparisons among individual populations and 13 for comparisons among different host groups and regions.

Relationships among representative genotypes (combinations of the alleles among the 14 microsatellite loci) from andiroba and other hosts of the LAC (Ferreira et al., 2010; Harrington et al., 2015; Oliveira et al., 2015a, 2017; Valdetaro et al., 2015) were examined in PAUP* (Swofford, 2003) using genetic distance (Nei's) matrices and UPGMA (unweigted pair group method with arithmetic mean) trees. Bootstrapping tests utilized 1000 replications.

Nei's genetic distance between populations based on allele frequencies and UPGMA were conducted using POPULATIONS 1.2.30 (Langella, 1999). Bootstrap values were calculated from 100 replications using POPULATIONS 1.2.30.

\subsection{Pathogenicity tests}

Three representative isolates from andiroba (CarAC-144B2, CarAM-ANDP1 and CarRR1-RR74), one isolate from eucalyptus (EucBA-SBS1), one from mango (ManCE-CEBS13), and one from teak (TecMT-QM29) were used in two inoculation experiments. All of the isolates were inoculated into andiroba seedlings (3-mo-old), into mango seedlings (cultivar Espada, 19-mo-old), into rooted cuttings of hybrid clone 1172 of E. urophylla x E. grandis (3-mo-old), and into rooted cuttings of teak (6-mo-old). The plants were transplanted into $2 \mathrm{~L}$ pots containing the substrate Carolina II (Carolina Soil do Brasil) supplemented with $6 \mathrm{~kg} \mathrm{~m}^{-3}$ of superphosphate and $1.5 \mathrm{~kg} \mathrm{~m}^{-3}$ Basacote $^{\circledR}$ (19-6-10) (ComPo do Brasil). However, the teak plants were grown in potting mix with soil, sand and Carolina II (in proportion 1-1-1). Both experiments were conducted in a completely randomized design, consisting of two factors (host $\times$ isolate) with seven replications per treatment. The plants were wounded (approx. 3-mm deep) with a sterile scalpel at $3 \mathrm{~cm}$ above the soil level. A volume of $500 \mu \mathrm{L}$ of the inoculum $\left(3 \times 10^{6}\right.$ spores $\left.\mathrm{ml}^{-1}\right)$ was pipetted into the wound and the inoculation site wrapped with Parafilm to reduce desiccation and contamination. The control plants were wounded and treated with the same volume of sterile distilled water. In the first experiment (inoculated 13 May 2016), the plants were incubated in a greenhouse with an average temperature of $23{ }^{\circ} \mathrm{C}$ (range $8-45^{\circ} \mathrm{C}$ ). In the second experiment (inoculated 24 June 2016), the plants were incubated in a growth chamber maintained at $25^{\circ} \mathrm{C}$ $\left(22-30.5^{\circ} \mathrm{C}\right)$ with a $12 \mathrm{~h}$ photoperiod and $96 \mu \mathrm{M}$ photons $/ \mathrm{s} / \mathrm{m}^{2}$. After $60 \mathrm{~d}$, the length of xylem discoloration was measured. The carrot baiting method (Moller and Devay, 1968) was used to re-isolate the fungus. The variance analyses (ANOVA) (including isolate, host, and experiment) and Fisher's Protected LSD test $(P<0.01)$ were conducted on the means of the length of xylem discoloration using Statistica ${ }^{\circledR}$ software (StatSoft Inc.).

\section{Results}

\subsection{Sample collection and fungal isolation}

The fungus was isolated from 73 of 194 samples of blighted seeds and seedlings at the four locations (Fig. 1). In Acre and the two sites in Roraima, we observed seedlings showing symptoms of Ceratocystsis seedling blight (Fig. 2B) as well as fungal sporulation (Fig. 2C and E) and, in some cases, the presence of perithecia on the stem of the seedlings (Fig. 2D). In Amazonas, we collected only seeds, which were covered by fungal sporulation and, in some cases, showed gummosis (Fig. 2F). Particularly high percentages of symptomatic seeds and seedlings were found directly below mature andiroba trees, where seed density was high.

\subsection{ITS rDNA haplotypes}

Of the 73 isolates, 72 were succeeded to obtain the ITS sequences, only one isolate from Amazonas (CarAM-ANDP2) could not be directly sequenced for the ITS region. This isolate had mixed ITS sequences, that is, the electropherogram generated with the ITS1F primer initially gave clean reads, and then overlapping peaks followed an indel position (Harrington et al., 2014; Oliveira et al., 2015a).

The maximum parsimony analysis found 9 trees of 321 steps with 99 variable characters, 73 of which were parsimony informative in the alignment of $613 \mathrm{bp}$ (TreeBase 23626). In comparisons with the sequences of other LAC sequences, three new ITS haplotypes (ITS17, ITS17a and ITS18) were identified among the sequenced isolates from andiroba (Fig. 3). The ITS haplotype numbers follow the designations by Harrington et al. (2011, 2014) and Oliveira et al. (2015a). The ITS17 and ITS17a sequences were 

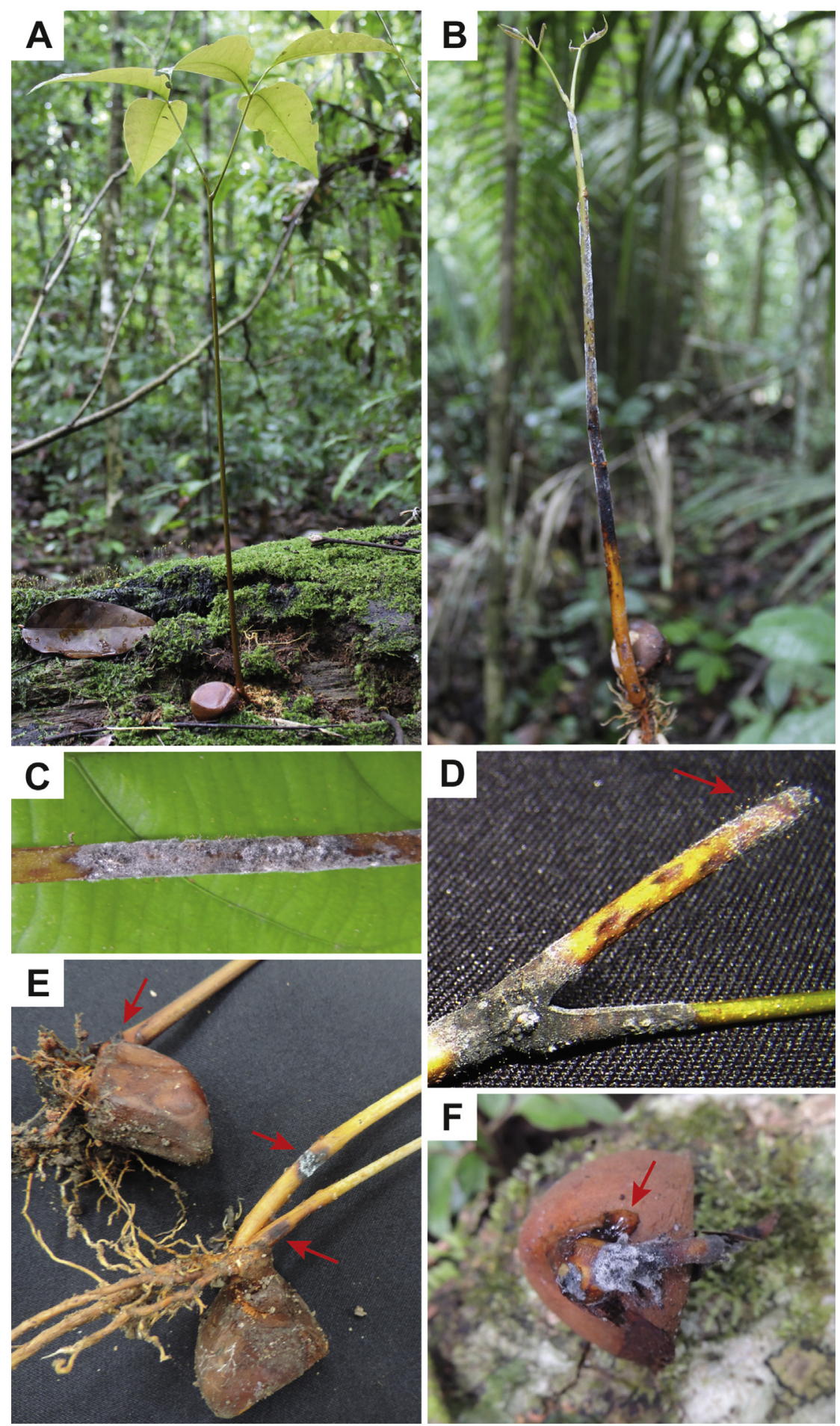

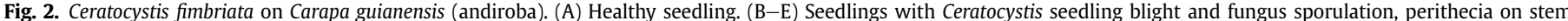

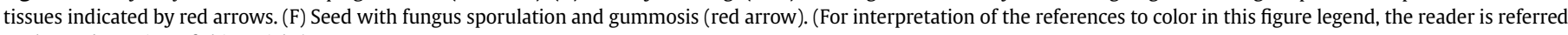
to the Web version of this article.)

found in two isolates from Acre, and the rest of the isolates had the ITS18 sequence.

\subsection{Phylogenetic analyses}

Fifteen isolates from andiroba representing the Acre, Amazonas and Roraima populations were sequenced for mating type genes. Each of the 15 isolates had the identical sequence for MAT-1 (MAT1-
1-2). Minor variation in the MAT-2 (MAT1-2-1) sequence also was found among the isolates. The MAT1-1-2 alignment had 1040 characters, and the MAT1-2-1 alignment had 1131 characters, with 62 characters varying among the sequences from andiroba and those of other members of the LAC.

Sequences of the two mating type genes were combined for phylogenetic analyses because self-fertile strains have the genes tightly linked in the mating type locus, and the genes are not 


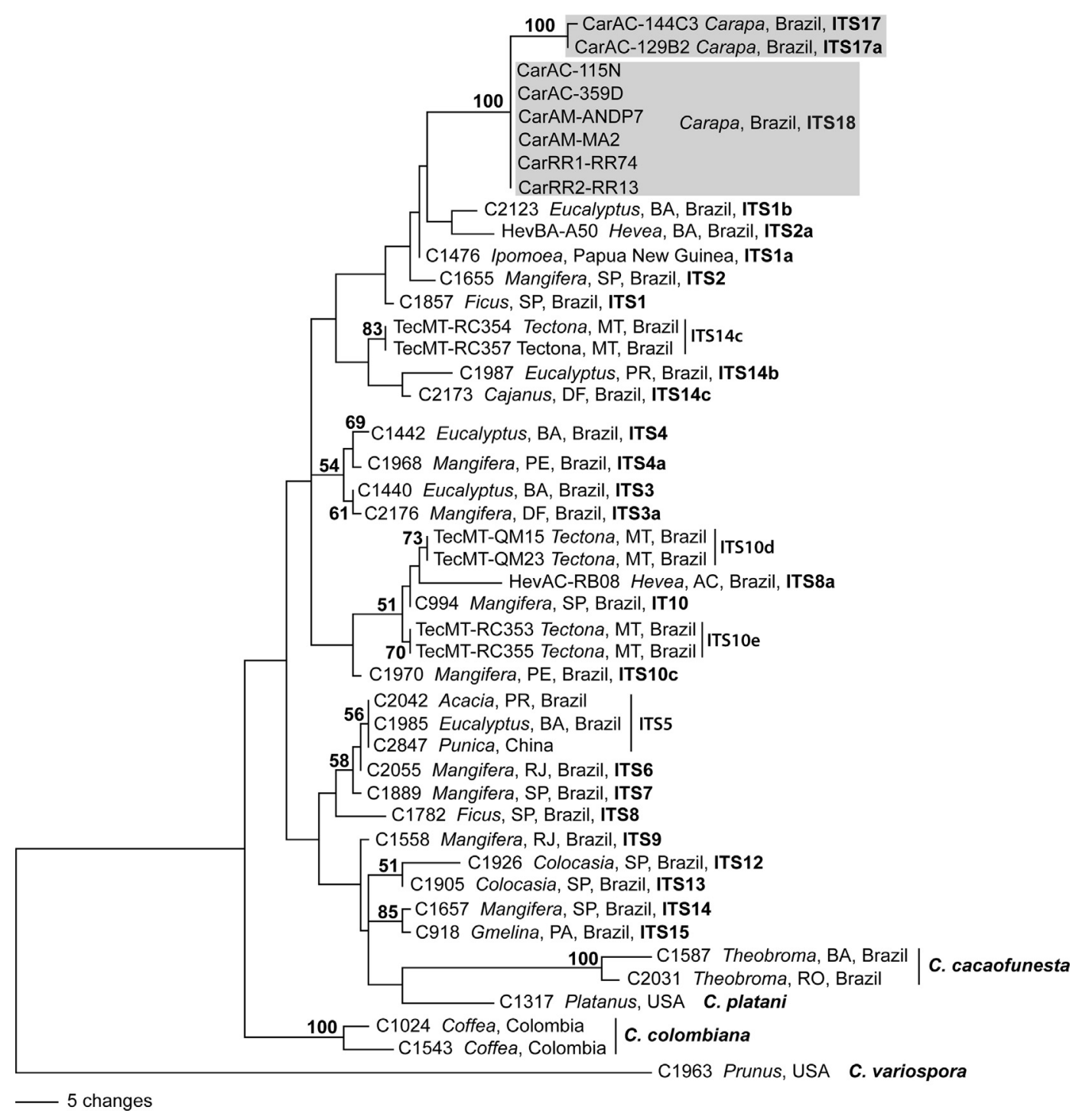

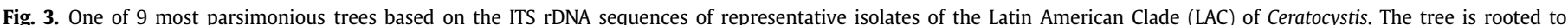

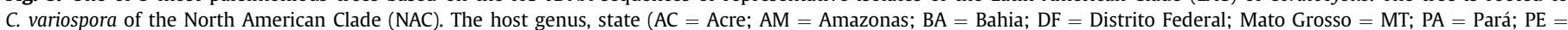

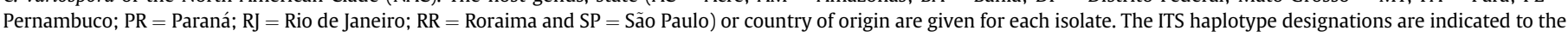
right. Bootstrap values greater than $50 \%$ are indicated on appropriate branches. Scale bar indicates base pair differences.

thought to recombine in crosses (Harrington et al., 2014). A partition homogeneity test (PHT) performed for the combined dataset of MAT-1 and MAT-2 genes showed that they could be combined $(P=0.26)$ (Cunningham, 1997; Barker and Lutzoni, 2002). The combined dataset of sequences of isolates from andiroba and other representatives of the LAC (Harrington et al., 2014) had an alignment of 2171 characters (TreeBase 23 626). The number of variable characters was 373 , and 84 of those characters were parsimony informative. Maximum parsimony (MP) analysis found a single tree of 494 steps, with homoplasy index (HI), consistency index (CI), rescaled consistency index (RC), and retention index (RI) of 0.0486 , $0.9514,0.8816$ and 0.9266 , respectively.

Evolution model HKY $+\mathrm{G}$ was selected and incorporated into the Bayesian analysis, and the level of convergence from two parallel runs after 1000000 generations had a mean standard deviation of split frequencies of 0.00665 . The likelihood tree from Bayesian analysis had a very similar topology to that of the MP tree. Therefore, the parsimony tree was selected for illustration (Fig. 4). Other species from the LAC (C. cacofunesta, C. colombiana, and
C. platani) had bootstrap support of $100 \%$ and posterior probability (PP) of 1.00 (Fig. 4).

The MAT haplotypes from andiroba were placed among the other Brazilian isolates of $C$. fimbriata. Three new mating haplotypes ( $4 \mathrm{e}, 4 \mathrm{f}$ and $4 \mathrm{~g}$, named following the nomenclature proposed by Harrington et al., 2014) were found among the 15 isolates. Haplotype 4e was found in four isolates (two from Roraima and two from Acre), haplotype $4 \mathrm{f}$ was found in one isolate from Acre, and the rest of the isolates had haplotype $4 \mathrm{~g}$, as did an isolate from cacao in Trinidad and Tobago (C1584). The isolates from andiroba were closely related to each other, with good bootstrap and posterior probability support.

\subsection{Mating experiments}

The MAT-1 testers from andiroba successfully crossed with the MAT-2 testers of most of the other Brazilian isolates of $C$. fimbriata (Table 2). In successful crosses, there were many fully developed perithecia with thick, creamy ascopore masses within $7 \mathrm{~d}$ of 


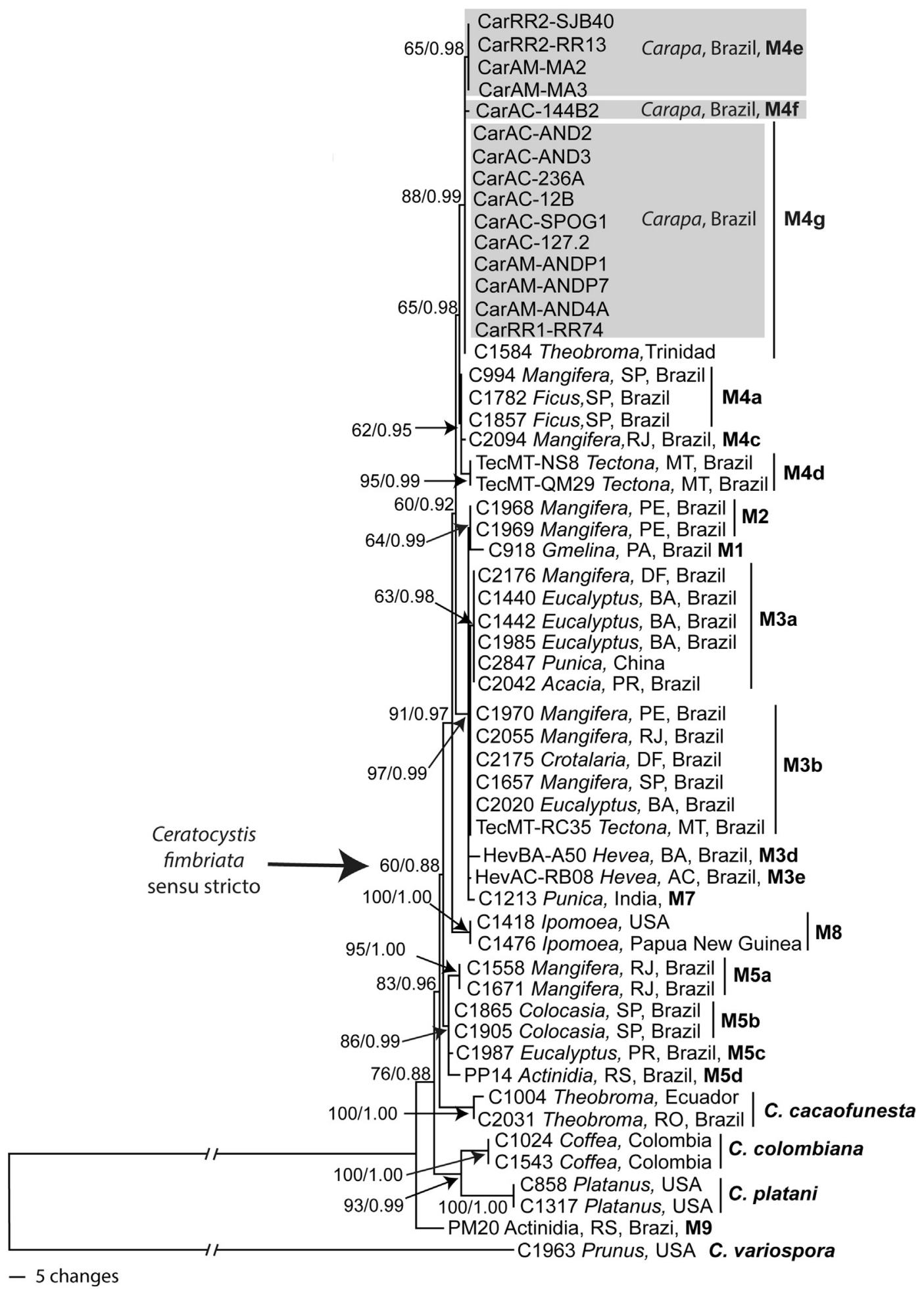

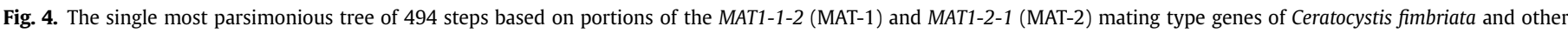

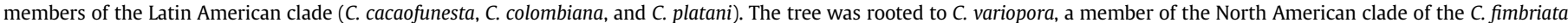

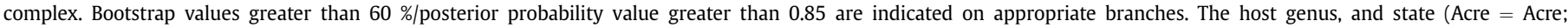

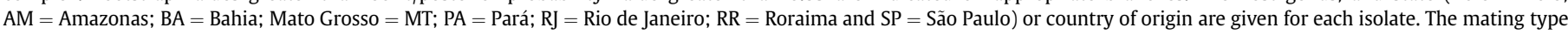
haplotype designations are indicated on the right. Scale bar indicates base pair differences.

spermatization (Fig. 5A), and microscopic examination showed abundant, normal appearing ascopores (Fig. 5C). Ascopores masses from normal crosses streaked onto fresh MYEA plates showed mixed phenotypes among the resulting colonies, demonstrating that the ascopores were not due to a selfing. In unsuccessful crosses, only a few or no perithecia were produced, the ascospores masses were watery (Fig. 5B), and microscopic examination showed mostly misshapen or empty ascospores (Fig. 5D). 
Table 2

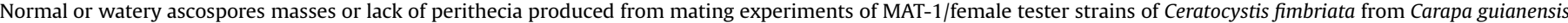
and MAT-2/male tester strains of C. platani and C. fimbriata from Tectona grandis, Eucalyptus spp., Mangifera indica and Ipomoea batatas.

\begin{tabular}{|c|c|c|c|c|c|c|c|c|c|}
\hline \multirow[t]{3}{*}{ Species } & \multirow[t]{3}{*}{ Host } & \multirow[t]{3}{*}{ MAT1, Female } & \multicolumn{7}{|l|}{ MAT2, Male ${ }^{a}$} \\
\hline & & & \multirow{2}{*}{$\frac{\text { Tectona grandis }}{\text { TecMT-SI69sec }}$} & \multirow{2}{*}{$\frac{\text { Eucalyptus spp. }}{\text { C1347sec }}$} & \multicolumn{3}{|c|}{ Mangifera indica } & \multirow{2}{*}{$\frac{\text { Ipomoea batatas }}{\text { C1418sec }}$} & \multirow{2}{*}{$\frac{\text { C. platani }}{\text { C1343sec }}$} \\
\hline & & & & & SEMS2-11sec & SESP5-1sec & ERRJ1-10sec & & \\
\hline \multirow[t]{4}{*}{ C. fimbriata } & \multirow[t]{4}{*}{ Carapa guianensis } & CarRR1-RR74ss & Normal $^{\mathrm{b}}$ & Normal & Normal & Normal & Normal & Normal & Watery $^{c}$ \\
\hline & & CarAC-127-2ss & Normal & Normal & Normal & Normal & Normal & Normal & Watery \\
\hline & & CarAM-MA2ss & Normal & Normal & Perithecia $^{\mathrm{d}}$ & Normal & - & - & - \\
\hline & & CarAM-MA3ss & Normal & Normal & Normal & $-^{\mathrm{e}}$ & - & - & - \\
\hline
\end{tabular}

${ }^{a}$ sec = strains from MAT2, self-sterile sectors recovered from self-fertile isolates; ss = MAT1, female isolates with protoperithecia

b Normal = masses with abundant, normal appearing ascospores.

c Watery $=$ masses with few, mostly misshapen ascospores, or no ascopores.

d Perithecia $=$ Perithecia only, no ascospore mass.

e $-=$ no perithecia produced.
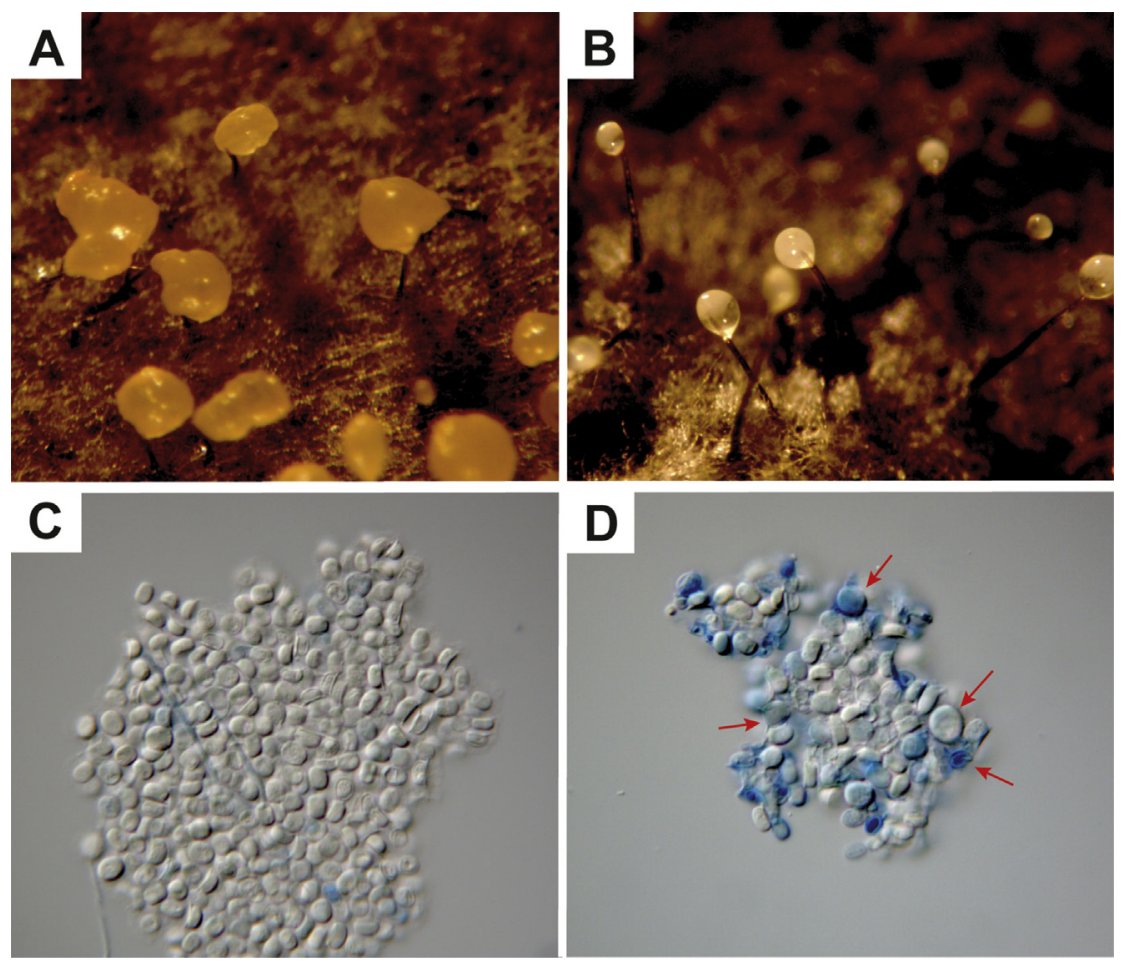

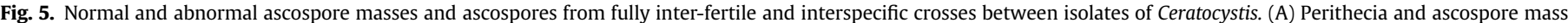

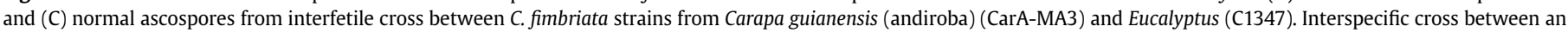

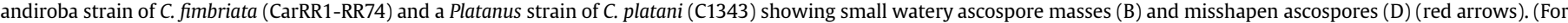
interpretation of the references to color in this figure legend, the reader is referred to the Web version of this article.)

\subsection{Microsatellite analyses}

Of the 14 microsatellite loci tested on the 73 andiroba isolates, eight loci were monomorphic and six were polymorphic (Table 3). The UPGMA tree based on Nei's genetic distance (Fig. 6) found 14 genotypes among the andiroba isolates, and these grouped separately from other $C$. fimbriata isolates with high support (95\%). Three of the 14 andiroba genotypes (AMSAT1, AMSAT2 and AMSAT3) were found in more than one of the four populations (Fig. 6).

The UPGMA tree based on allele frequencies of populations (Fig. 7) showed that andiroba populations grouped separately from the other Brazilian populations of $C$. fimbriata with high bootstrap support (100\%). The UPGMA tree also separated other populations associated with different hosts and geographic locations.
Nei's gene diversity $(H)$ and Stoddart and Taylor's genotypic diversity $(G)$ for populations from andiroba were compared to other Brazilian populations (Table 4). The Amazonas population showed greater gene and genotypic diversity $(H=0.1486 ; G=3.3889)$ than the other andiroba populations. The Brazilian populations from Eucalyptus $(H=0.3212 ; G=8.2371)$, mango in the Northeast Brazil $(H=0.3758 ; G=7.9237)$ and taro $(H=0.1530 ; G=6.7460)$ had greater gene and genotypic diversity than andiroba populations $(H=0.1271 ; G=4.8055)$ (Table 4).

\subsection{Pathogenicity tests}

At the end of the inoculation experiments, none of the host plants were killed, but wilt symptoms were observed in some inoculated plants of some host species. Re-isolations of the 
Table 3

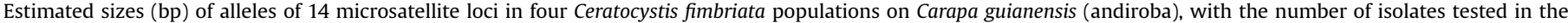
population shown in parentheses.

\begin{tabular}{|c|c|c|c|c|}
\hline Microsatellite Locus & CarAC (13) & CarRR1 (26) & CarRR2 (24) & CarAM (10) \\
\hline AAG8 & 183 & 183 & 183 & 183 \\
\hline AAG9 & 400 & 400 & 400 & 400 \\
\hline CAA9 & $251(5)^{\mathrm{a}}, 263(8)$ & 190 & $159(1), 190(23)$ & $190(3), 263(7)$ \\
\hline CAA10 & 127 & 127 & 127 & 127 \\
\hline CAA15 & 324 & 324 & 324 & 324 \\
\hline CAA38 & $159(7), 168(5), 214(1)$ & $159(20), 180(2), 205(4)$ & $159(1), 171(1), 205(22)$ & $159(5), 171(2), 214(3)$ \\
\hline CAA80 & 317 & $296(1), 299(25)$ & 299 & $296(3), 299(5), 317(2)$ \\
\hline CAG5 & 317 & 317 & 317 & 317 \\
\hline CAG15 & 252 & 252 & 252 & 252 \\
\hline CAG900 & 194 & 194 & 194 & 194 \\
\hline CAT1 & 254 & $248(1), 254(25)$ & $248(8), 254(16)$ & $248(3), 254(7)$ \\
\hline CAT12 & 377 & 365 (1), 377 (25) & 377 & 377 \\
\hline GACA6K & 215 & 215 & 215 & 215 \\
\hline GACA60 & 187 & 187 (25), 207 (1) & 187 & 187 \\
\hline
\end{tabular}

a The number of isolates with that allele size in parentheses.

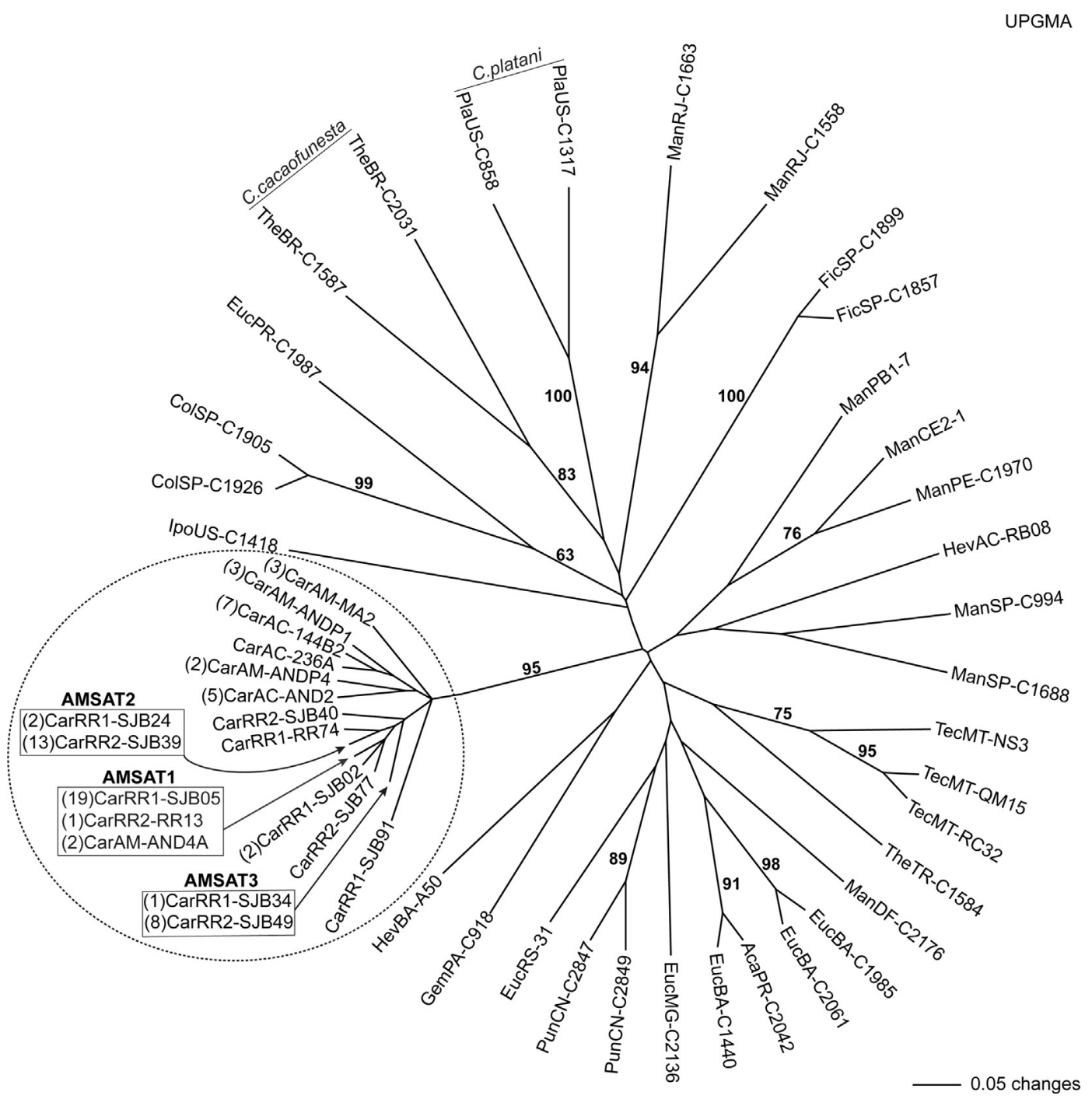

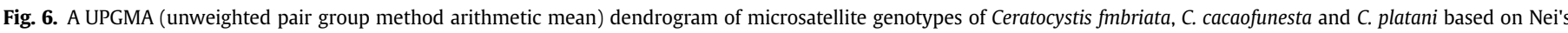

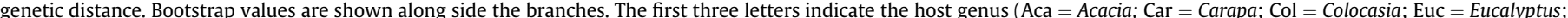

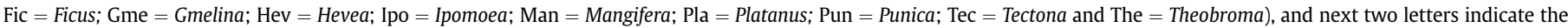

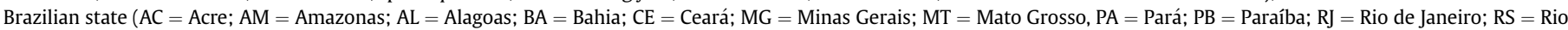

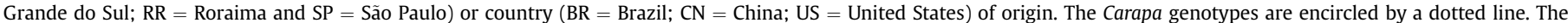

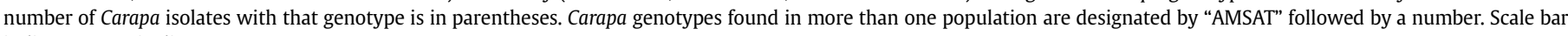
indicates genetic distance. 


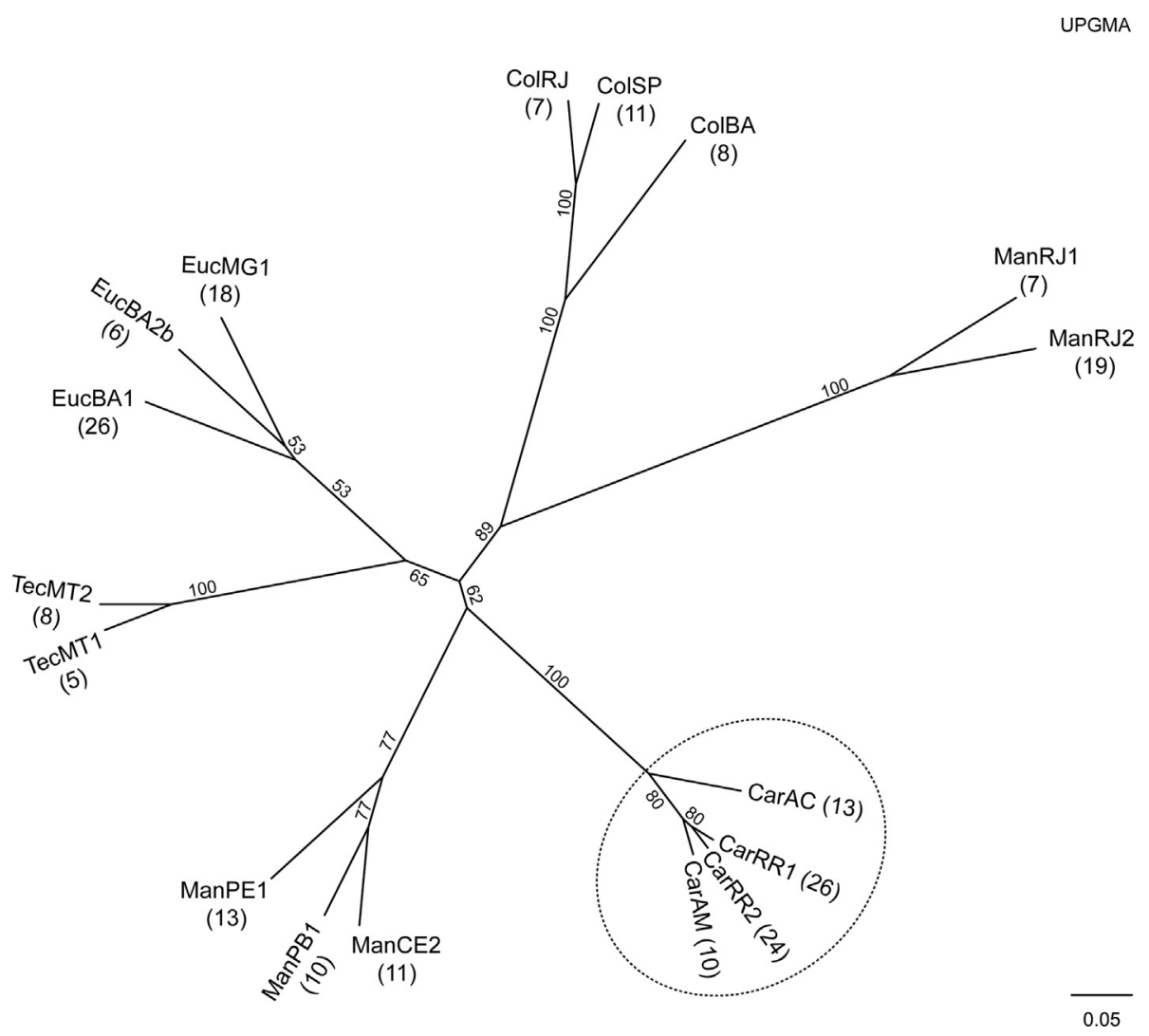

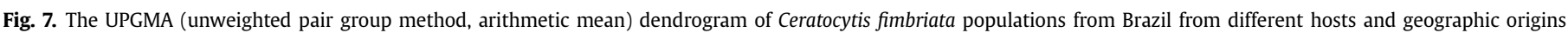

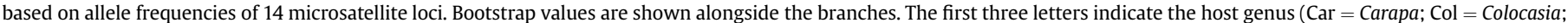

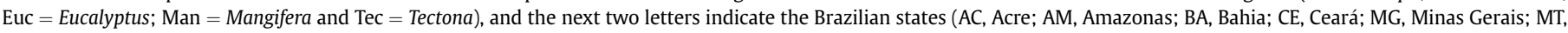

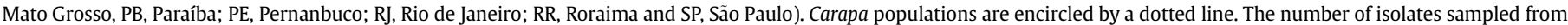
each population is in parentheses.

Table 4

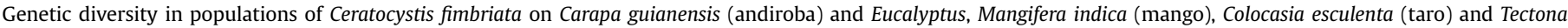
grandis (teak) based on 14 microsatellite loci.

\begin{tabular}{|c|c|c|c|c|c|c|c|}
\hline \multirow[t]{2}{*}{ Host } & \multirow[t]{2}{*}{ Population } & \multirow[t]{2}{*}{ City/State } & \multirow[t]{2}{*}{ No. Isolates } & \multirow[t]{2}{*}{ No. geno-types } & \multirow{2}{*}{$\begin{array}{l}\text { Genotypic } \\
\text { diversity }(G)^{\mathrm{a}}\end{array}$} & \multicolumn{2}{|c|}{ Nei's gene diversity $(H)$} \\
\hline & & & & & & All isolates & Clone-corrected \\
\hline \multirow[t]{5}{*}{ Carapa guianensis } & AM & Boa Vista de Ramos/Amazonas & 10 & 4 & 3.3889 & 0.1486 & 0.1429 \\
\hline & RR2 & São João da Baliza/Roraima & 24 & 5 & 2.5114 & 0.0486 & 0.0857 \\
\hline & $A C$ & Rio Branco/Acre & 13 & 3 & 2.3364 & 0.0735 & 0.0794 \\
\hline & RR1 & São João da Baliza/Roraima & 26 & 6 & 2.2843 & 0.0482 & 0.1230 \\
\hline & & All Andiroba Isolates & 73 & 14 & 4.8055 & 0.1271 & 0.1713 \\
\hline \multirow[t]{3}{*}{ Tectona grandis } & TecMT1 & Nossa Senhora do Livramento/Mato Grosso & 5 & 2 & 2.0000 & 0.0686 & 0.1071 \\
\hline & TecMT2 & São José dos Quatro Marcos/Mato Grosso & 8 & 1 & 1.0000 & 0.0000 & 0.0000 \\
\hline & & All Tectona isolates & 13 & 2 & 1.7423 & 0.0913 & 0.1071 \\
\hline \multirow[t]{3}{*}{ Colocasia esculenta } & ColRJ & Rio de Janeiro/Rio de Janeiro & 7 & 5 & 3.7692 & 0.1953 & 0.2343 \\
\hline & ColSP & Sorocaba/São Paulo & 11 & 3 & 2.4069 & 0.0472 & 0.0635 \\
\hline & & All Colocasia isolates & 18 & 8 & 6.7460 & 0.1530 & 0.2277 \\
\hline \multirow[t]{3}{*}{ Mangifera indica- Rio de Janeiro } & ManRJ1 & São Fidelis/Rio de Janeiro & 7 & 4 & 3.3809 & 0.0816 & 0.1071 \\
\hline & ManRJ2 & São Fidelis/Rio de Janeiro & 19 & 4 & 1.7895 & 0.0973 & 0.1875 \\
\hline & & All Mangifera isolates from Rio de Janeiro & 26 & 8 & 2.4717 & 0.2001 & 0.2076 \\
\hline \multirow{3}{*}{ Mangifera indica - Northeast } & NECE2 & Brejo Santo/Ceará & 11 & 7 & 4.1515 & 0.2904 & 0.3469 \\
\hline & NEPB1 & Conde/Paraíba & 10 & 6 & 3.7539 & 0.3814 & 0.3889 \\
\hline & & All Mangifera isolates from the Northeast & 21 & 13 & 7.9237 & 0.3758 & 0.3889 \\
\hline \multirow[t]{3}{*}{ Eucalyptus spp. } & EucMG1 & Curvelo/Minas Gerais & 18 & 14 & 4.5899 & 0.3122 & 0.3309 \\
\hline & EucBA1 & Eunápolis/Bahia & 26 & 13 & 3.8735 & 0.2162 & 0.2832 \\
\hline & & All Eucalyptus isolates & 44 & 27 & 8.2371 & 0.3212 & 0.3535 \\
\hline
\end{tabular}

a Stoddart \& Taylor's genotypic diversity $(\mathrm{G})$ with rarefaction. Values of $\mathrm{G}$ with rarefaction for individual populations ranged from 1.0 (only one genotype in the population)

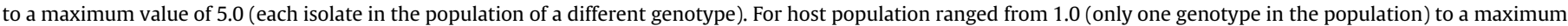
value of 13.0 (each isolate in the population of a different genotype). 
pathogen from discoloured tissue of the inoculated plants consistently yielded typical colonies of $C$. fimbriata, even if the lesions were small. Some un-inoculated plants (controls), mostly eucalyptus, showed some wilting of leaves, but these plants had only limited discoloration at the wound site and the pathogen was not re-isolated. In the growth chamber, the temperature was uniform $\left(22{ }^{\circ} \mathrm{C}-30.5^{\circ} \mathrm{C}\right)$ during the experiment and the relative humidity was very high $(90.76 \%$ ), resulting in edema formation on leaves and stems of andiroba. On the other hand, the light intensity was relatively low $\left(95.6 \mu \mathrm{M}\right.$ photons $\left./ \mathrm{s} / \mathrm{m}^{2}\right)$ and some teak, mango and eucalyptus plants suffered attack from cochineal scales in the growth chamber.

In some cases, the lesions (xylem discoloration) of inoculated plants in the growth chamber was somewhat more extensive than the lesions in the greenhouse experiment (Table 5), and more inoculated plants wilted, but the results of the two experiments were generally similar. In both experiments, wilting occurred in some plants that were inoculated with isolates that originated from that host. Andiroba, mango and eucalyptus isolates inoculated into their respective hosts typically induced dark discoloration that extended continuously from the inoculation point, especially above the inoculation point.

The initial multifactorial ANOVA of length of xylem discoloration showed significant variation between two experiments, so data from the two experiments were analyzed separately. In both the greenhouse and growth chamber analyses, significant variation was found among the isolates (greenhouse, $F=14.44, \mathrm{P}<0.0001$; growth chamber, $F=47.64, \mathrm{P}<0.0001$ ), the hosts (greenhouse, $F=25.99, \mathrm{P}<0.0001$; growth chamber, $F=83.36, \mathrm{P}<0.0001)$, and isolate $\times$ host interaction (greenhouse, $F=15.43, \mathrm{P}<0.0001$; growth chamber, $F=48.58, \mathrm{P}<0.0001$ ).

In both experiments, the three andiroba isolates caused significantly larger lesions in andiroba plants than did the other isolates, whose induced lesion lengths did not differ from those of the controls (Table 5). Variation in the extent of xylem discoloration (pathogen aggressiveness) was found among the andiroba isolates tested. In both experiments, mango and eucalyptus showed longer lesions than the other hosts when inoculated with their respective isolates. The lesions on mango induced by non-host isolates were discontinuous and narrow, unlike the lesions induced by the mango isolate. On mango plants in the growth chamber, all isolates induced xylem discoloration significantly greater than in the controls, but the mango isolate caused significantly greater lesion length. Although the lesions were relatively small in teak compared to the other hosts, isolate TecMT-QM29 from teak caused significantly more xylem discoloration than that seen in the control plants.

\section{Discussion}

The phylogenetic analysis using sequences of mating type genes (MAT1-1-1 and MAT1-2-1) and ITS-rDNA sequences showed that isolates from andiroba from four sites in three states in the Amazon Basin form a strongly supported lineage closely related to other Brazilian isolates and isolates from sweet potato, on which C. fimbriata was originally described (Halsted, 1890). Three similar mating type sequences were found among the isolates from andiroba, and one of the three sequences matched a $C$. fimbriata isolate from cacao in Trinidad (C1584), but that cacao isolate differs from $C$. cacaofunesta and was not pathogenic to cacao plants in earlier studies (Baker et al., 2003; Engelbrecht and Harrington, 2005). That isolate could have been introduced on plant material to Trinidad, but the isolates from andiroba are believed to represent a native Amazonian population of $C$. fimbriata.

Although the population on andiroba was phylogenetically distinct, mating studies showed that they were interfertile with the sweet potato type strain of $C$. fimbriata, on which the species name is based, as well as with Brazilian Eucalyptus, mango and teak strains that are considered to be $C$. fimbriata. In contrast, the isolates from andiroba were intersterile with $C$. platani, another species from the LAC (Engelbrecht and Harrington, 2005). Thus, the isolates from andiroba would be considered $C$. fimbriata using the biological species concept (Harrington et al., 2011, 2014; Oliveira et al., 2015a).

Microsatellite analysis identified 14 genotypes among the andiroba isolates, and these isolates grouped separately from other Brazilian genotypes in UPGMA analyses. Three of the 14 genotypes were widely distributed within and among the andiroba populations, and one of the genotypes was found in both Roraima and Amazonas. The genotypic diversity and the gene diversity values of the populations on andiroba were somewhat low, but comparable to some Brazilian populations of C. fimbriata on other hosts, strongly suggesting that the andiroba isolates represent natural subpopulations and not introduced genotypes. The analyses of populations based on allele frequencies showed the andiroba subpopulations to be closely related to each other and clearly differentiated from other Brazilian populations on other hosts and other regions in Brazil.

There appears to be a strong regional differentiation of populations of $C$. fimbriata in Brazil, likely due to its soilborne nature, limited dispersal by insects, and a preponderance of selfing (Ferreira et al., 2010, 2017; Harrington, 2013; Oliveira et al., 2015a). The isolates from andiroba represent the first fully studied populations of $C$. fimbriata from the Amazon rain forest. Other differentiated populations of $C$. fimbriata in Brazil have been proposed to be associated with forest types: isolates from Eucalyptus and mango

Table 5

Mean xylem discoloration $(\mathrm{cm})$ caused by Ceratocystis fimbriata isolates inoculated into four hosts in greenhouse and growth chamber experiments.

\begin{tabular}{|c|c|c|c|c|c|c|c|c|}
\hline \multirow[t]{2}{*}{ Isolates } & \multicolumn{2}{|c|}{ Carapa guianensis } & \multicolumn{2}{|c|}{ Tectona grandis } & \multicolumn{2}{|c|}{ Eucalyptus spp. } & \multicolumn{2}{|c|}{ Mangifera indica } \\
\hline & $\mathrm{GH}^{\mathrm{b}}$ & $\mathrm{GC}^{\mathrm{C}}$ & GH1 & GC & GH1 & GC & $\mathrm{GH}$ & GC \\
\hline CarAM-ANDP1 ${ }^{\text {a }}$ & $9.13 a$ & 8.69ab & $2.00 \mathrm{ab}$ & $1.69 \mathrm{~b}$ & $3.25 c$ & $3.38 b c$ & $4.25 b$ & $6.47 \mathrm{~b}$ \\
\hline CarAC-C144B2 & 7.38ab & $10.31 \mathrm{a}$ & $1.69 b$ & $1.75 b$ & $2.94 \mathrm{c}$ & $3.08 c$ & $4.38 \mathrm{~b}$ & $7.96 \mathrm{~b}$ \\
\hline CarRR-RR174 & $5.38 \mathrm{bc}$ & $10.88 \mathrm{a}$ & $1.88 \mathrm{ab}$ & $1.75 b$ & $3.88 \mathrm{bc}$ & $3.06 c$ & $3.81 \mathrm{~b}$ & $7.03 \mathrm{~b}$ \\
\hline TecMT-QM29 & $3.75 \mathrm{~cd}$ & $5.03 b c$ & $2.69 \mathrm{a}$ & $2.81 \mathrm{a}$ & $3.44 \mathrm{bc}$ & $4.50 \mathrm{bc}$ & $4.34 \mathrm{~b}$ & $7.56 b$ \\
\hline EucBA-SBS1 & $3.19 \mathrm{~cd}$ & $3.94 b c$ & 2.06ab & $1.81 \mathrm{~b}$ & $16.00 \mathrm{a}$ & $28.38 \mathrm{a}$ & $6.88 \mathrm{~b}$ & $9.26 \mathrm{~b}$ \\
\hline MangCE-CEBS13 & $2.50 \mathrm{~cd}$ & $3.54 \mathrm{bc}$ & $2.06 \mathrm{ab}$ & $1.81 \mathrm{~b}$ & $5.88 \mathrm{~b}$ & $5.81 b$ & $15.63 a$ & $13.94 \mathrm{a}$ \\
\hline Control & $1.81 \mathrm{~d}$ & $1.69 c$ & $1.69 b$ & $1.69 \mathrm{~b}$ & $2.13 c$ & $2.00 \mathrm{c}$ & $2.69 b$ & $2.13 c$ \\
\hline
\end{tabular}

a The first three letters indicate the host genus (Car = Carapa; Euc = Eucalyptus; Man = Mangifera and Tec = Tectona) and next two letters indicate the Brazilian state

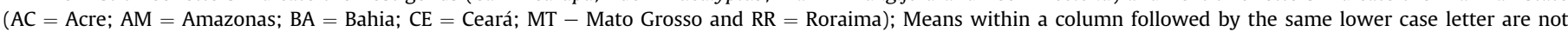
significantly different $(P<0.01)$ based on Fisher's protected least significant difference.

b $\mathrm{GH}=$ Green House.

c $\mathrm{GC}=$ Growth Chamber. 
native to Cerrado and Caatinga forest types, respectively (Ferreira et al., 2010; Oliveira et al., 2015a); taro isolates along with mango isolates that seem to be native to the coastal Mata Atlântica forest type in Rio de Janeiro (Baker et al., 2003; Harrington et al., 2014; Oliveira et al., 2015a, 2017; Silveira et al., 2006); and kiwifruit isolates in southern Brazil (Ferreira et al., 2017). The Amazonian populations are unique in that andiroba is native to the basin, and it is not a cultivated host. Seeds of the plant are collected from natural forests for extraction of oils, but it is highly unlikely that human activity brought strains from one region of the Amazon to the other. Rather, native strains uniquely pathogenic to andiroba appear to be naturally distributed across the Amazon Basin.

The inoculation tests showed host specialization to andiroba, which is one of the few documented cases of a LAC member of Ceratocystis showing specialization to a host native to the Americas. C. cacaofunesta is believed native to the Upper Amazon and is specialized to infect cacao and relatives (Baker et al., 2003; Engelbrecht et al., 2007b), C. platani is native to eastern USA and is specialized to infect Platanus spp., and isolates from Xanthosoma sagittifolium and Syngonium spp. are phylogenetically related and specialized to infect aroids (Araceae) (Baker et al., 2003; Thorpe et al., 2005). Host specialization has been thought to be a driver of speciation in the group, and it has been considered a phenotypic character warranting species designations (Harrington and Rizzo, 1999; Engelbrecht and Harrington, 2005). However, Ceratocystis species have been mostly studied on non-native crop plants, with which they have not evolved (Engelbrecht and Harrington, 2005; Ferreira et al., 2010; Harrington et al., 2002; Johnson et al., 2005; Oliveira et al., 2015a). Isolates from certain non-native hosts have shown higher levels of aggressiveness to those hosts, but not all isolates from those populations have shown the same level of aggressiveness, that is, the populations as a whole are not truly host-specialized (Baker et al., 2003; Harrington et al., 2011; Oliveira et al., 2015b, 2016; Piveta et al., 2016; Zauza et al., 2004).

Host specialization to andiroba could be used as a phenotypic character to delineate this narrowly defined phylogenetic lineage as a new species (Harrington and Rizzo, 1999). However, unlike C. cacaofunesta and C. platani, the andiroba strains fall within the C. fimbriata lineage and were interfertile with a sweet potato isolate, which was phylogenetically related to $C$. fimbriata isolates on other hosts in Ecuador and Colombia (Li et al., 2017). Introduced genotypes of $C$. fimbriata that likely originated from the Northeast of Brazil have been named C. manginecans M. van Wyk, A. Adawi \& M.J. Wingf., C. mangivora M. van Wyk \& M.J. Wingf., C. mangicola M. van Wyk \& M.J. Wingf., C. acaciovora Tarigan \& M. van Wyk, and C. eucalypticola M. van Wyk \& M.J. Wingf., but genetic and mating studies clearly indicate that these are genotypes of a single species (Harrington et al., 2014; Li et al., 2017; Oliveira et al., 2015a). These genotypes and andiroba isolates are interfertile with each other and sweet potato isolates of C. fimbriata and are morphologically indistinguishable (Li et al., 2017; Oliveira et al., 2015a). In spite of interfertility among the genotypes and with $C$. fimbriata isolates from sweet potato, the species name $C$. manginecans could be used to represent most of the Brazilian populations that tend to be aggressive on mango and eucalyptus, as well as teak and andiroba strains. Other populations on mango and taro from Rio de Janeiro and kiwifruit from Rio Grande do Sul (Ferreira et al., 2017; Oliveira et al., 2017) would also need new species descriptions in this scenario. Regardless, description of the andiroba pathogen as a new species would leave either $C$. manginecans or C. fimbriata paraphyletic.

A careful review of South American populations and species in the $C$. fimbriata complex will be necessary to develop a workable species concept that could be consistently applied to this important group of plant pathogens. The andiroba population appears to be native to the Amazon and uniquely pathogenic as a seed and seedling blight pathogen on a native tree species in forests with only limited human disturbance, but recognition of this population as a species does not appear warranted. In lieu of a new species name, this population could be recognized as a special form (forma specialis) of $C$. fimbriata, and we propose Ceratocystis fimbriata f. sp. carapa. Forma specialis is not a formal taxonomic rank but has been used to recognize physiologically specialized strains of plant pathogens. The other demonstrated host-specialized strain within C. fimbriata is the sweet potato pathogen, for which we propose C. fimbriata f. sp. ipomoea. With these informal designations and in the absence of other distinguishing phenotypic features, we propose to retain the species name $C$. fimbriata for South American and introduced strains that fall within the monophyletic lineage that is interfertile with the sweet potato pathogen.

\section{Acknowledgements}

This work was supported by CNPq, FAPEMIG and CAPES. We would like to thank Walter Leandro Coutinho for assistance for collecting andiroba samples from Boa Vista do Ramos and Parintins, Amazonas. We are also grateful to Clonar Resistência a Doenças Florestais for use of their inoculation facilities and plant maintenance.

\section{References}

Albuquerque, F.C., Duarte, M.L.R., Silva, H.M., 1972. Ocorrência do mofo cinzento (Ceratocystis fimbriata) da seringueira. In: Seminário Nacional da Seringueira, pp. 125-128. Cuiabá, MS.

Alfenas, A.C., Mafia, R.G., 2016. Métodos Em Fitopatologia, second ed. Viçosa, MG.

Baker, C.J., Harrington, T.C., Krauss, U., Alfenas, A.C., 2003. Genetic variability and host specialization in the Latin American clade of Ceratocystis fimbriata. Phytopathology 93, 1274-1284.

Barker, F.K., Lutzoni, F.M., 2002. The utility of the incongruence length difference test. Sist. Biol. 51, 625-637.

Carvalho, M.B., 1938. Sobre dois insetos nocivos à mangueira. Boletim da Secretaria da Agricultura. Indústria e Comércio do Estado de Pernambuco. 3, 130-132.

Cunningham, C.W., 1997. Can three incongruence tests predict when data should be combined? Mol. Biol. Evol. 14, 733-740.

Engelbrecht, C.J.B., Harrington, T.C., Steimel, J., Capretti, P., 2004. Genetic variation in eastern North American a putatively introduced populations of Ceratocystis fimbriata f. platani. Mol. Ecol. 13, 2995-3005.

Engelbrecht, C.J.B., Harrington, T.C., 2005. Intersterility, morphology, and taxonomy of Ceratocystsi fimbriata on sweet potato, cacao, and sycamore. Mycologia 97, $57-69$.

Engelbrecht, C.J.B., Harrington, T.C., Alfenas, A.C., Suarez, C., 2007a. Genetic variation in populations of the cacao wilt pathogen, Ceratocystis cacaofunesta. Plant Pathol. 56, 923-933.

Engelbrecht, C.J.B., Harrington, T.C., Alfenas, A.C., 2007b. Ceratocystis wilt - a disease of increasing importance. Phytopathology 97, 1648-1649.

Ferreira, F.A., Demuner, A.M.M., Demuner, N.L., Pigato, S., 1999. Murcha de Ceratocystis em eucalipto no Brasil. Fitopatol. Bras. 24, 284.

Ferreira, E.M., Harrington, T.C., Thorpe, D.J., Alfenas, A.C., 2010. Genetic diversity and interfertility among highly differentiated populations of Ceratocystis fimbriata in Brazil. Plant Pathol. 59, 721-735.

Ferreira, M.A., Harrington, T.C., Alfenas, A.C., Mizubuti, E.S.G., 2011. Movement of genotypes of Ceratocystis fimbriata within and among Eucalyptus plantations in Brazil. Phytopathology 101, 1005-1012.

Ferreira, M.A., Harrington, T.C., Piveta, G., Alfenas, A.C., 2017. Genetic variability suggests that three populations of Ceratocystis fimbriata are responsible for the Ceratocystis wilt epidemic on kiwifruit on Brazil. Trop. Plant Pathol. 42, 86-95.

Firmino, A.C., Tozze Jr., H.J., Furtado, E.L., 2012. First report of Ceratocystis fimbriata causing wilt in Tectona grandis in Brazil. New Dis. Rep. 25, 24.

Gardes, M., Bruns, T.D., 1993. ITS primers with enhanced specificity for basidiomycetes - application to the identification of mycorrhizae and rusts. Mol. Ecol. 2, $113-118$.

Grünwald, N.J., Goodwin, S.B., Milgroom, M.G., Fry, W.E., 2003. Analysis of genotypic diversity data for populations of microorganisms. Phytopathology 93, 738-746.

Halfeld-Vieira, B.A., Zilli, J.E., Nechet, K.L., Pereira, G.M.D., Souza, G.R., 2012. First record of Ceratocystis fimbriata on Carapa guianensis. New Dis. Rep. 26, 13.

Halsted, B.D., 1890. Some fungous diseases of the sweet potato. The black rot. N. J. Agric. Exp. Stn. 76, 7-14. 
Harrington, T.C., McNew, D.L., 1997. Self-fertility and unidirectional mating type switching in Ceratocystis coerulescens, a filamentous ascomycete. Curr. Genet. 32, 52-59.

Harrington, T.C., Rizzo, D.M., 1999. Defining species in fungi. In: Worrall, J.J. (Ed.), Structure and Dynamics of Fungal Populations. Kluwer Academics, Dordrecht, Netherlands, pp. 43-71.

Harrington, T.C., Pashenova, N.V., McNew, D.L., Steimel, J., Konstantinov, M.Y., 2002. Species delimitation and host specialization of Ceratocystis laricicola and C. polonica to larch and spruce. Plant Dis. 86, 418-422.

Harrington, T.C., Thorpe, D.J., Alfenas, A.C., 2011. Genetic variation and variation in aggressiveness to native and exotic hosts among Brazilian populations of Ceratocystis fimbriata. Phytopathology 101, 555-566.

Harrington, T.C., 2013. Ceratocystis diseases. In: Gonthier, P., Nicolotti, G. (Eds.), Infectious Forest Diseases. CAB International, Wallingford, UK, pp. 230-255.

Harrington, T.C., Kazmi, M.R., Al-Sadi, A.M., Ismail, S.I., 2014. Intraspecific and intragenomic variability of ITS rDNA sequences reveals taxonomic problems in Ceratocystis fimbriata sensu stricto. Mycologia 106, 224-242.

Harrington, T.C., Huang, Q., Ferreira, M.A., Alfenas, A.C., 2015. Genetic analyses trace the Yunnan, China population of Ceratocystis fimbriata on pomegranate and taro to populations on Eucalyptus in Brazil. Plant Dis. 99, 106-111.

Herrero-Jáuregui, C., Guariguata, M.R., Cárdenas, D., Vilanova, E., Robles, M., Licona, J.C., Nalvarte, W., 2013. Assessing the extent of "conflict of use" in multipurpose tropical forest trees: a regional view. J. Environ. Manag. 130, 40-47.

Johnson, J.A., Harrington, T.C., Engelbrecht, C.J.B., 2005. Phylogeny and taxonomy of the North American clade of the Ceratocystis fimbriata complex. Mycologia 97, 1067-1092.

Klimas, C.A., Cropper Jr., W.P., Kainer, K.A., Wadt, L.H.O., 2012. Viability of combined timber and non-timber harvests for one species: a Capara guianensis case study. Ecol. Model. 246, 147-156.

Langella, O., 1999. Populations 1.2.30: Population Genetic Software (Individuals or Population Distances, Phylogenetic Trees). http://bioinformatics.org/ tryphon/ populations/. (Accessed 1 July 2015).

Li, Q., Harrington, T.C., McNew, D., Li, J., Huang, Q., Somasekhara, Y.M., Alfenas, A.C., 2016. Genetic bottlenecks for two populations of Ceratocystis fimbriata on sweet potato and pomegranate in China. Plant Dis. 100, 2266-2274.

Li, Q., Harrington, T.C., McNew, D., Li, J., 2017. Ceratocystis uchidae, a new species on Araceae in Hawai'i and Fiji. Mycoscience 58, 398-412.

Moller, W.J., Devay, J.E., 1968. Carrot as a species-selective isolation medium for Ceratocystis fimbriata. Phytopathology 58, 123-124.

Muchovej, J.J., Albuquerque, F.C., Ribeiro, G.T., 1978. Gmelina arborea - a new host of Ceratocystis fimbriata. Plant Dis. Rep. 62, 717-719.

Nylander, J.A.A., 2004. MrModeltest Version 2. Program Distributed by the Author: Evolutionary Biology Centre. Uppsala University.

Ocasio-Morales, R.G., Tsopelas, P., Harrington, T.C., 2007. Origin of Ceratocystis platani on native Platanus orientalis in Greece and its impact on natural forests. Plant Dis. 91, 901-904.

Oliveira, L.S.S., Harrington, T.C., Ferreira, M.A., Damacena, M.B., Al-Sadi, A.M., AlMahmooli, I.H.S., Alfenas, A.C., 2015a. Species or genotypes? Reassessment of four recently described species of the Ceratocystis wilt pathogen, Ceratocystis fimbriata, on Mangifera indica. Phytopathology 105, 1229-1244.

Oliveira, L.S.S., Guimarães, L.M.S., Ferreira, M.A., Nunes, A.S., Pimenta, L.V.A., Alfenas, A.C., 2015b. Aggressiveness, cultural characteristic and genetic variation of Ceratocystis fimbriata on Eucalyptus spp. For. Pathol. 45, 505-514.
Oliveira, L.S.S., Damacena, M.B., Guimarães, L.M.S., Siqueira, D.L., Alfenas, A.C., 2016. Ceratocystis fimbriata isolates on Mangifera indica have different levels of aggressiveness. Eur. J. Plant Pathol. 145 (4), 847-856.

Oliveira, L.S.S., Harrington, T.C., Ferreira, M.A., Freitas, R.G., Alfenas, A.C., 2017. Populations of Ceratocystis fimbriata on Colocasia esculenta and other hosts in the Mata Atlântica region in Brazil. Plant Pathol. 67, 97-106.

Piveta, G., Alfenas, A.C., Muniz, M.F.B., Valdebenito-Sanhuezas, R.M., Ferreira, M.A. 2013. Ocorrência de Ceratocystis fimbriata em kiwi (Actinidia deliciosa) no Sul do Brasil. Rev. Bras. Frutic. 35 (2), 665-669.

Piveta, G., Ferreira, M.A., Muniz, M.F.B., Valdetaro, D., Valdebenito-Sanhueza, R.V., Harrington, T.C., Alfenas, A.C., 2016. Ceratocystis fimbriata on kiwifruit (Actinidia spp.) in Brazil. N. Z. J. Agr. Res. 44, 13-24.

R Development Core Team, 2007. R: Uma Linguagem e Ambiente para Computação Estatística. R Foundation for Statistical Computing, Viena. http://www.Rproject.org.

Ronquist, F., Huelsenbeck, J.P., 2003. MRBAYES 3: Bayesian phylogenetic inference under mixed models. Bioinformatics 19, 1572-1574.

Silva, A.C., Cândido, T.S., Sales, N.L., Harrington, T.C., 2017. First report of Ceratocystis wilt caused by Ceratocystis fimbriata on Caryocar brasiliensis trees in Brazil. Plant Dis. 101, 1822.

Silveira, F.S., Harrington, T.C., Mussi-Dias, V., Engelbrecht, C.J.B., Alfenas, A.C. Silva, C.R., 2006. Annona squamosa, a new host of Ceratocystis fimbriata. Fitopatol. Bras. 31, 394-397.

Simpson, M.C., Wilken, P.M., Coetzee, M.P.A., Wingfield, M.J., Wingfield, B.D., 2013. Analysis of microsatellite markers in the genome of the plant pathogen Ceratocystis fimbriata. Fungal Biol. 117, 545-555.

Souza, C.R., Lima, R.M.B., Azevedo, C.P., Rossi, L.M.B., 2006. Andiroba (Carapa guianensis Aubl.). Manaus, AM. Comunicado Técnico, n.48, 26p.: Embrapa.

Swofford, D.L., 2003. PAUP*. Phylogenetic Analysis Using Parsimony (*and Othe Methods). Version 4. Sinauer Associates, Sunderland, Massachusetts.

Steimel, J., Engelbrecht, C.J.B., Harrington, T.C., 2004. Development and characterization of microsatellite markers for fungus Ceratocystis fimbriata. Mol. Ecol. Notes 4, 215-218.

Thorpe, DJ. Harrington, T.C. Uchida, JY, 2005. Pathogenicity, internal transcribed spacer-rDNA variation, and human dispersal of Ceratocystis fimbriata on the family araceae. Phytopathology 95, 316-323.

Tropicos.org Tropicos, 2016. Missouri Botanical Garden. http://www.tropicos.org (Accessed 04 April 2016)

Valarini, P.J., Tokeshi, H., 1980. Ceratocystis fimbriata, causal agent of fig dieback, and its control. Summa Phytopathol. 6, 102-106.

Valdetaro, D.C.O.F., Oliveira, L.S.S., Guimaraes, L.M.S., Harrington, T.C., Ferreira, M.A. Freitas, R.G., Alfenas, A.C., 2015. Genetic variation, morphology and pathogenicity of Ceratocystis fimbriata in Hevea brasiliensis in Brazil. Trop. Plant Pathol. 40, 184-192.

Vinhote, M.L.A., 2014. Uso e manjeo de recursos florestais não madeireiros em unidades de conservação estaduais na área de influência da BR 319. Dissertação. Instituto Nacional de Pesquisas Amazônicas, AM.

White, T.J., Bruns, T., Lee, S., Taylor, J., 1990. Amplification and direct sequencing of fungal ribosomal rna genes for phylogenetics. In: Innis, M.A., Gelfand, D.H. Sninsky, J.J., White, T.J. (Eds.), PCR Protocols: a Guide to Methods and Applications. Academic Press, San Diego, pp. 315-322.

Zauza, E.A.V., Alfenas, A.C., Harrington, T.C., Silva, J.F., 2004. Resistance of Eucalyptus clones to Ceratocystis fimbriata. Plant Dis. 88, 758-760. 